\title{
Household and farm attributes affecting adoption of smallholder timber management practices by tree growers in Gunungkidul region, Indonesia
}

\author{
Gerhard Sabastian • Peter Kanowski • \\ Digby Race • Emlyn Williams • \\ James M. Roshetko
}

Received: 28 February 2013/Accepted: 15 January 2014/Published online: 30 January 2014

(C) Springer Science+Business Media Dordrecht 2014

\begin{abstract}
Farm household characteristics determine the success of programs promoting agroforestry systems and practices. This paper reports household and farm factors affecting the adoption of timber management practices by smallholders in the Gunungkidul region, Central Java, Indonesia. The research used three logistic regression analysis models—based on each household and farm characteristic, and a composite of both together-to identify the key factors influencing farmers' adoption and management decisions, and their relative importance. A sample of 152 farmers who managed their trees
\end{abstract}

G. Sabastian · J. M. Roshetko

World Agroforestry Centre, Bogor, Indonesia

G. Sabastian ( $($ )

Jalan CIFOR, Situ Gede, Sindang Barang,

Bogor Barat 16115, Jawa Barat, Indonesia

e-mail: g.manurung@cgiar.org

P. Kanowski

Center for International Forestry Research, Bogor, Indonesia

P. Kanowski - D. Race

Fenner School of Environment \& Society, Australian

National University, Canberra, ACT, Australia

E. Williams

Statistical Consulting Unit, Australian National

University, Canberra, ACT, Australia

J. M. Roshetko

Winrock International, Bogor, Indonesia primarily for timber production was compared to a sample of 115 farmers with similar socio-economic characteristics who did not. The household condition and composite models identified both on-farm and offfarm gross incomes as significant factors affecting farmers' decisions to manage timber trees. The models confirmed that farmers with larger farms, and with higher on- and off-farm incomes, were more likely to manage their trees for timber production. These results have implications for extension programs that promote adoption of commercial timber management by smallholders in the case study and similar regions.

Keywords Household livelihood - Tree growing · Adoption - Logistic regression · Gunungkidul $\cdot$ Indonesia

\section{Introduction}

There is now a wealth of literature addressing issues associated with the adoption of innovations in farming systems (e.g. reviews by Baumgart-Getz et al. 2012; McGinty et al. 2008; Pannell et al. 2006; Mercer 2004; Pattanayak et al. 2003). Those studies were initiated in part to evaluate if advocates of innovations, including of agroforestry systems, had adequately understood farmers' motivations (e.g. Byron 2001), the household and farm factors that influenced tree growing by farmers (e.g. Saxena and Ballabh 1995), the importance of biophysical factors in determining adoption 
(Pattanayak et al. 2003), and had sufficiently integrated research on socioeconomic and biophysical issues (Mercer 2004; Mercer and Miller 1998).

This research addresses a number of these issues in the context of the adoption of smallholder timbermanagement practices by tree growers in the Gunungkidul region of Java, Indonesia. It develops logistic models to explore the importance of both household (socio-economic) and farm (biophysical) factors in the adoption of these practices. The study recognizes the value of investigating both the characteristics of existing traditional agroforestry practices and household livelihood objectives as the basis for developing appropriate strategies for encouraging farmers to grow trees and improve management of existing agroforestry systems (Nair and Dagar 1991; Saxena and Ballabh 1995; Fisher and Bunch 1996). This study takes as a starting point understanding the livelihood strategies' perspective of farmers, under which farmers are assumed to be "resource optimizers". As Scherr (1995) and Ellis (2000) explain, in selecting their livelihood strategies, farmers continuously optimize the expected utility of land, trees, family labor, cash and other resources to meet their household objectives, while at the same time seeking to minimize critical risk factors.

Deforestation and land degradation were widespread in the Gunungkidul region by the 1950s as a result of clearing marginal land for agricultural production to accommodate the needs of a growing population (Nibbering 1999). However, since at least 50 years ago, the widespread adoption of agroforestry through the establishment of a tree-based agricultural system practiced by smallholder farmers (Roshetko et al. 2007) has transformed the farmland of the Gunungkidul region. The cultivation of timber, fruit and fodder trees to improve family livelihoods has also regenerated soils. Trees are grown along the boundaries of fields and terraces in dryland systems at wide spacing to limit competition with annual crops. On hillsides and other areas not prioritized for annual crops, trees tend to be grown in blocks or small plantations, with timber species dominating.

Given their different skills, interests, resources and constraints, tree growing may not be the preferred choice for every farmer (Bertomeu 2004; Santos et al. 2012). Most farmers in Gunungkidul grow timber trees as a form of savings (capital accumulation) for when income is needed in emergency situations
(Rohadi et al. 2011). This study builds on earlier work in the same region, which (i) found that farmers' tree-growing decisions were shaped by available agricultural technologies, responses to declining soil quality, household labor supply, market forces, government pricing policies for tree products, and a national reforestation program (van Der Poel and van Dijk 1987; Filius 1997; Nibbering 1999); (ii) investigated the ecological aspects of farms and the sociocultural and economic factors of households that had an effect on tree growing (Soerianegara and Mansuri 1994; Manurung et al. 2008); and (iii) established that farmers in Gunungkidul were hampered by limited access to relevant information and to inputs such as good quality planting materials and fertilizers, and thus did not practice proactive silvicultural management for their timber trees (Sabastian et al. 2009).

However, none of the previous studies were conducted at the level of detail we report here. This paper (i) examines the associations between variable household factors, farm characteristics and timber management relevant to smallholder timber production systems in Gunungkidul; and (ii) develops models that identify the key factors and the magnitude of their influence on farmers' adoption of timber tree management choices. The hypothesis tested in this study is that high income and more land has a positive influence on the choices of farmers in the management of timber trees.

\section{Materials and methods}

Site description

The district of Gunungkidul is situated in the southeast of the special province of Yogyakarta, Java, between $7^{\circ} 46^{\prime}-7^{\circ} 09^{\prime}$ latitude and $110^{\circ} 21^{\prime}-110^{\circ} 50^{\prime}$ longitude. This district is hilly in its northern zone (Baturagung mountain range), relatively flat in the middle zone (Wonosari plateau), and hilly in the western, southern and eastern zones (Sewu mountain range) (Waltham et al. 1983). Slopes ranging from 2 to $40 \%$ cover about $71 \%$ of the area of the district. Approximately $74 \%$ of the district has karsts soils, predominantly in the Sewu mountain range; Vertisols are dominant in the Wonosari plateau. The Baturagung mountain range is covered by Entisol and Alfisol soil types. The elevation of this district varies from 0 to $800 \mathrm{~m}$ 
above sea level (masl) (Statistics of Gunungkidul Regency 2009). The climate in the Gunungkidul area is strongly influenced by the wet northwest monsoon (November-April/May) and dry southeast monsoon (June-September/October). The average annual rainfall in the area is between 1,500 and 2,000 $\mathrm{mm}$, and the average temperature is between 24 and $26{ }^{\circ} \mathrm{C}$ (Sudiharjo and Notohadiprawiro 2006).

In 2008 , the population was 686,772 persons in 144 villages, with a density of 462 inhabitants $/ \mathrm{km}^{2}$. The total area of Gunungkidul district is 148,536 ha. Landuse allocation consists of wetland farms (5.3\%), dryland systems $(45.3 \%)$, homegardens (17.1\%), woodlots $(17.3 \%)$, state forests $(8.8 \%)$, ponds $(0.1 \%)$ and others $(6.2 \%)$. The major crops grown in the agricultural landscape of Gunungkidul are wetland paddy, dryland paddy, maize, cassava, sweet potatoes, peanuts, soybeans and green peanuts. The four most common timber species planted on smallholder farms are teak (Tectona grandis), mahogany (Swietenia macrophylla), sonokeling (Dalbergia latifolia) and acacia (Acacia auriculiformis) (Statistics of Gunungkidul Regency 2009).

Trees are cultivated scattered over the fields and along contours in smallholder timber production systems, in both dryland systems (tegalan) and homegardens (pekarangan). Socioeconomic and farm conditions determine the functions trees serve. Typically, they meet a number of purposes, such as wood production, boundary demarcation, overstorey for shade-demanding crops, protection against erosion, shelter, and insurance during periods of scarcity. To better serve these functions, timber trees may be incorporated in various densities and arrangements in existing farm niches, for instance, in homegardens and in dryland systems as hedgerow timber-intercropping and woodlots (Sabastian et al. 2009).

Research design, data sampling and analysis

Households are the decision-making unit for land management. Primary data were collected through face-to-face interviews with the heads of households in the study area. This study compared households involved in management of timber trees to households of similar socioeconomic characteristics not involved in their management. Households considered involved in "timber management" were those that cultivated timber trees using silvicultural techniques-such as quality planting material, weeding, fertilizing, pruning and harvesting (including thinning) on their land. Sabastian et al. (2009) reported that nearly threequarters of farmers $(72.0 \%)$ considered the quality of local planting material; most farmers $(72.9 \%)$ weeded their smallholder timber production systems to enhance growth of timber trees and annual crops by minimizing weed competition; also they prioritized the use of chemical and organic fertilizers on annual crops, with left-over fertilizers applied to timber trees. Branch pruning in a manner that left a $10-15 \mathrm{~cm}$ branch stub was practiced on $62.5 \%$ of the 227 smallholder timber production systems inventoried. Thinning was an uncommon activity in the systems; most farmers considered thinning a type of harvesting.

Information and data on farm characteristics and household conditions were collected at various levels in order to gain a comprehensive view of the management of timber trees in the systems. Three categories of data represented household conditions, namely (i) demographic and cultural aspects; (ii) labor resources and financial factors and (iii) timber market specifications. The three categories corresponding to farm characteristics were (i) landholding status; (ii) land biophysical attributes and (iii) land accessibility (Table 1). To cover all levels of information, a detailed questionnaire was developed and modified through a literature review and a pre-test study using the Participatory Rural Appraisal (PRA) technique (in this case, group discussion with key farmers and field observations). A sample of household heads was purposively selected based on three parameters: (i) experience in planting teak trees; (ii) the variation in farmer's welfare which was based on landholding sizes and (iii) location of farmlands, representing the three main landscapes of the Gunungkidul region (Waltham et al. 1983). Based on these parameters, the number of selected household heads was 267 persons from seven villages. All household condition data were collected between May and September 2007, while data on land biophysical attributes was collected during October 2009 (Rohadi et al. 2011).

The process of data analysis was divided into three steps. The first step was to compare the means of each explanatory variable for two farmers' categories (no timber management farmers and timber management farmers) using a $t$ test. Then, the direction and strength of associations between the variables were examined. 
Table 1 Explanatory variables in the models, their abbreviations and descriptions

\begin{tabular}{|c|c|c|c|c|}
\hline $\begin{array}{l}\text { Determinant } \\
\text { factor }\end{array}$ & Information level & $\begin{array}{l}\text { Explanatory variable and } \\
\text { the abbreviation }\end{array}$ & Variable description & $\begin{array}{l}\text { Variable } \\
\text { type }\end{array}$ \\
\hline \multirow[t]{9}{*}{$\begin{array}{l}\text { Household } \\
\text { conditions }\end{array}$} & \multirow[t]{4}{*}{$\begin{array}{l}\text { Demographic and } \\
\text { cultural aspects }\end{array}$} & $\begin{array}{l}\text { Number of household members } \\
(\mathrm{NHM})\end{array}$ & $\begin{array}{l}\text { Including working and } \\
\text { dependent }\end{array}$ & Continuous \\
\hline & & Household head age (HHA) & Household head age & Continuous \\
\hline & & $\begin{array}{l}\text { Household head literacy skills } \\
\text { (HHLS) }\end{array}$ & Household head literacy skills & Categorical \\
\hline & & $\begin{array}{l}\text { Timber tree planting experience } \\
\text { (TTPE) }\end{array}$ & $\begin{array}{l}\text { Years of adopting timber-based } \\
\text { farming system }\end{array}$ & Continuous \\
\hline & \multirow[t]{4}{*}{$\begin{array}{l}\text { Labor resources and } \\
\text { financial factors }\end{array}$} & $\begin{array}{l}\text { Working household members } \\
\text { (WHM) }\end{array}$ & On-farm plus off-farm members & Continuous \\
\hline & & $\begin{array}{l}\text { On-farm working members } \\
\text { (OFWM) }\end{array}$ & Excluding off-farm members & Continuous \\
\hline & & Gross on-farm income (GONFI) & Agricultural and tree products & Continuous \\
\hline & & Gross off-farm income (GOFFI) & $\begin{array}{l}\text { Non-agricultural and non-tree } \\
\text { products }\end{array}$ & Continuous \\
\hline & $\begin{array}{r}\text { Timber market } \\
\text { specifications }\end{array}$ & $\begin{array}{l}\text { Timber product specification } \\
\text { (TPS) }\end{array}$ & $\begin{array}{l}\text { Knowledge of farmer of timber } \\
\text { product specifications }\end{array}$ & Categorical \\
\hline \multirow{9}{*}{$\begin{array}{l}\text { Farm } \\
\text { characteristics }\end{array}$} & \multirow[t]{3}{*}{ Landholding status } & Total area managed (TAM) & Area owned and tenanted & Continuous \\
\hline & & Number of parcels (NP) & With different land-use systems & Continuous \\
\hline & & Area owned (AO) & Excluding tenanted and rented & Continuous \\
\hline & \multirow[t]{4}{*}{$\begin{array}{l}\text { Land biophysical } \\
\text { attributes }\end{array}$} & Soil fertility (SF) & $\begin{array}{l}\text { Fertile (productive) or } \\
\text { degraded caused by soil } \\
\text { erosion }\end{array}$ & Categorical \\
\hline & & Farm surface $(\mathrm{FS})$ & Karsts and non-karsts covered & Categorical \\
\hline & & Soil depth (SD) & $\begin{array}{l}\text { Thin/shallow }(<25 \mathrm{~cm} \text { depth }) \\
\text { and thick }(\geq 25 \mathrm{~cm} \text { depth })\end{array}$ & Categorical \\
\hline & & Land position (LP) & Slopes or flat area & Categorical \\
\hline & \multirow[t]{2}{*}{ Land accessibility } & $\begin{array}{l}\text { Distance to nearest timber } \\
\text { trader (DNTT) }\end{array}$ & Distance to nearest market & Continuous \\
\hline & & $\begin{array}{l}\text { Distance to farmer's house } \\
\text { (DFH) }\end{array}$ & Distance to home & Continuous \\
\hline
\end{tabular}

In the third step, explanatory variables were employed to develop models using logistic regression analysis.

\section{Logistic regression models}

Logistic regression analysis is a statistical method that builds and tests models to predict significance outcomes of a reasonable set of explanatory variables when the dependent (response) variable is binary (Tabachnick and Fidell 2007; Pallant 2007). The use of this method in examining the adoption of timber management practices is useful to planners and policy makers in developing suitable extension strategies to encourage farmers to adopt silvicultural management.
Three logistic regression models representing, respectively, household conditions, farm characteristics and a composite of the two were developed using SPSS 18.0 software (Pallant 2007).

The process of model building began with defining the dependent variable. The dependent variable that represented timber management (TM) was binary or categorical (0: 'no timber management' farmers; 1: 'timber management' farmers), while a final set of 18 explanatory variables was selected that reflected hypotheses for the strongest influence on farmers' decisions to manage their timber trees by implementing silvicultural practices (Table 1). In logistic regression analysis, nine explanatory variables_-number of 
household members (NHM), household head age (HHA), household head literacy skills (HHLS), timber tree planting experience (TTPE), working household members (WHM), on-farm working members (OFWM), gross on-farm income (GONFI), gross offfarm income of (GOFFI) and timber product specification (TPS)—were used to develop a household conditions model while another nine explanatory variables-total area managed (TAM), number of parcels (NP), area owned (AO), soil fertility (SF), farm surface (FS), soil depth (SD), land position (LP), distance to nearest timber trader (DNTT) and distance to farmer's house (DFH) - were used to develop a farm characteristics model. Next, all explanatory variables of the household condition and farm characteristic models were combined to develop a composite logistic regression model. The logistic regression model for each determinant factor utilized a natural $\log$ of odds and was specified as:

$\log \left\{\frac{E(Y \mid X)}{1-E(Y \mid X)}\right\}=\alpha+\beta X$

or

$E(Y \mid X)=\exp (\alpha+\beta X) /(1+\exp (\alpha+\beta X))$

where $E(Y \mid X)$ is the probability ( $p$ ) of land and timber tree management ( $\mathrm{Y}>0$ managing timber trees); $1-E(Y \mid X)$ is the probability $(p)$ of not managing land and timber trees; $\alpha$ is the intercept term; $\beta$ for $\beta_{1}$, $\beta_{2}, \beta_{3}$ and $\beta_{\mathrm{k}}$ are the coefficients associated with $X_{1}$, $\mathrm{X}_{2}, \mathrm{X}_{3}$ and $\mathrm{X}_{\mathrm{k}}$ of a number of explanatory variables.

The process of model building continued with the Forward Likelihood ratio method, using a Wald test (Pallant 2007). The Forward Likelihood ratio method was used to find significant variables and probability of timber management prediction; while the contribution or value of the statistic for each variable was tested using the Wald test. Starting with no variables in the model, the best explanatory variables were selected based on the significance of improvement in $-2 \log$ likelihood (-2LL). At each step, the variable that resulted in a significant change in -2LL was selected until there was no significant change with further additions of the variables. A significance value of 0.10 levels was adopted for the admission of the explanatory variables in the model.

To obtain good performance, each model was validated using the Omnibus test of model coefficients and the Hosmer-Lemeshow goodness of fit test. The Omnibus test of model coefficients indicates performance of a model in terms of 'goodness of fit' test by referring to a highly significant value $(p<0.05)$. In the Hosmer-Lemeshow goodness of fit test, poor fit is indicated by a significance value less than 0.05 , so to support the model a value greater than 0.05 is needed. Exp (B) value is the Odds Ratio (OR) for each explanatory variable (Pallant 2007). The OR represents the change in odds of being in one of the categories of outcome when the value of a predictor (explanatory variable) increases by one unit (Tabachnick and Fidell 2007).

\section{Results}

Characteristics of the two farmer categories

On average, household heads were 53 years old, with 28 years of timber tree management experience. Only $22 \%$ of household heads felt they had good knowledge of timber product market specifications. On average, $86 \%$ of household heads were literate. The average family size was four, with three members working, two of them on farm. Total income was relatively small considering the number of household members. On-farm income averaged IDR 4.16 million/year (USD 540.80/year in 2007) and off-farm activities such as running small kiosks, industrialized labor, carpentry and government employment contributed to annual income by around IDR 4.66 million/ year (USD 605.80/year in 2007). Households that managed timber had 1.3 times higher on-farm income than those did not manage for timber.

The data analysis suggests a simple comparison of the unconditional means in eighteen explanatory variables between the characteristics of 'timber management' farmers and 'no timber management' farmers (Table 2). Of the 18 variables tested, only gross onfarm income showed a statistically significant difference between no timber management and timber management populations, with a $p$ value less than 0.05 . Two other variables differed significantly at the $p<0.10$ levels: (i) household head literacy skills and (ii) timber product specifications. However, inclusion of these two variables did not significantly improve the logistic regression model. The significance levels of differences between the populations of no management farmers and management farmers in Table 2 suggests that smallholders who adopt management of 
Table 2 Characteristics of households in 18 explanatory variables

\begin{tabular}{|c|c|c|c|c|}
\hline \multirow[t]{2}{*}{ Explanatory variables } & \multirow[t]{2}{*}{ Unit } & \multicolumn{2}{|l|}{ Mean } & \multirow[t]{2}{*}{$p$ value } \\
\hline & & $\begin{array}{l}\text { No timber } \\
\text { management } \\
\text { farmers }(n=115)\end{array}$ & $\begin{array}{l}\text { Timber } \\
\text { management } \\
\text { farmers } \\
(n=152)\end{array}$ & \\
\hline \multicolumn{5}{|l|}{ Household conditions } \\
\hline Number of household members (NHM) & Person & 4.26 & 4.49 & 0.266 \\
\hline Household head age (HHA) & Year & 54.00 & 53.43 & 0.712 \\
\hline Household head literacy skills (HHLS) & $\begin{array}{l}\text { 0: no literacy; } \\
\text { 1: literacy skills }\end{array}$ & 0.83 & 0.90 & 0.072 \\
\hline Timber tree planting experience (TTPE) & Year & 28.31 & 28.54 & 0.899 \\
\hline Working household members (WHM) & Person & 2.82 & 2.99 & 0.232 \\
\hline On-farm working members (OFWM) & Person & 2.24 & 2.32 & 0.594 \\
\hline Gross on-farm income (GONFI) & Million IDR/year & 3.58 & 4.60 & 0.047 \\
\hline Gross off-farm income (GOFFI) & Million IDR/year & 4.31 & 4.92 & 0.501 \\
\hline Timber product specification (TPS) & $\begin{array}{l}\text { 0: no knowledge; } \\
\text { 1: knowledgeable }\end{array}$ & 0.17 & 0.26 & 0.084 \\
\hline \multicolumn{5}{|l|}{ Farm characteristics } \\
\hline Total area managed (TAM) & Hectare & 0.82 & 0.89 & 0.436 \\
\hline Number of parcels (NP) & Farm & 3.72 & 3.88 & 0.509 \\
\hline Area owned (AO) & Hectare & 0.70 & 0.75 & 0.650 \\
\hline Soil fertility (SF & 0: degraded; 1 : productive & 0.61 & 0.66 & 0.410 \\
\hline Farm surface $(\mathrm{FS})$ & $\begin{array}{l}0 \text { : karsts surface; } \\
\text { 1: non-karsts surface }\end{array}$ & 0.57 & 0.62 & 0.464 \\
\hline Soil depth (SD) & 0: shallow; 1: thick & 0.58 & 0.63 & 0.418 \\
\hline Land position (LP) & 0: flat area; 1 : slopes & 0.43 & 0.39 & 0.445 \\
\hline Distance to nearest timber trader (DNTT) & $\mathrm{Km}$ & 1.47 & 1.20 & 0.137 \\
\hline Distance to farmer's house (DFH) & $\mathrm{Km}$ & 0.81 & 0.73 & 0.294 \\
\hline
\end{tabular}

timber trees tended to have more on-farm income, better literacy skills and more knowledge about the specification of timber products in the market.

Association among individual explanatory and dependent variables

The strength and direction of association between individual household and farm attributes variables are shown in Table 3. Among the household condition factors, the number of household members showed a strong positive correlation with the number of working household members variable (0.70), but only a moderate relationship with the number of on-farm working household members (0.46). The working household member variable was also strongly and positively associated with on-farm working household members
(0.70). The association between the age of the household head and timber tree planting experience variables indicated a sturdy and positive correlation (0.72). However, household head's age was moderately and negatively associated with household head's literacy skills $(-0.32)$. Moreover, for farm characteristics, a highly positive correlation was shown with total area managed and area owned variables (0.82) and a moderate relationship between total area managed and number of parcels variables (0.41). Correlation between soil fertility and farm surface (0.73) and soil depth (0.72) were strongly positive, as was that between farm surface and soil depth (0.87). Soil fertility, farm surface and soil thickness variables showed moderate and negative relationships with land position: $-0.45,-0.59$ and -0.54 , respectively. The associations between household condition and farm 


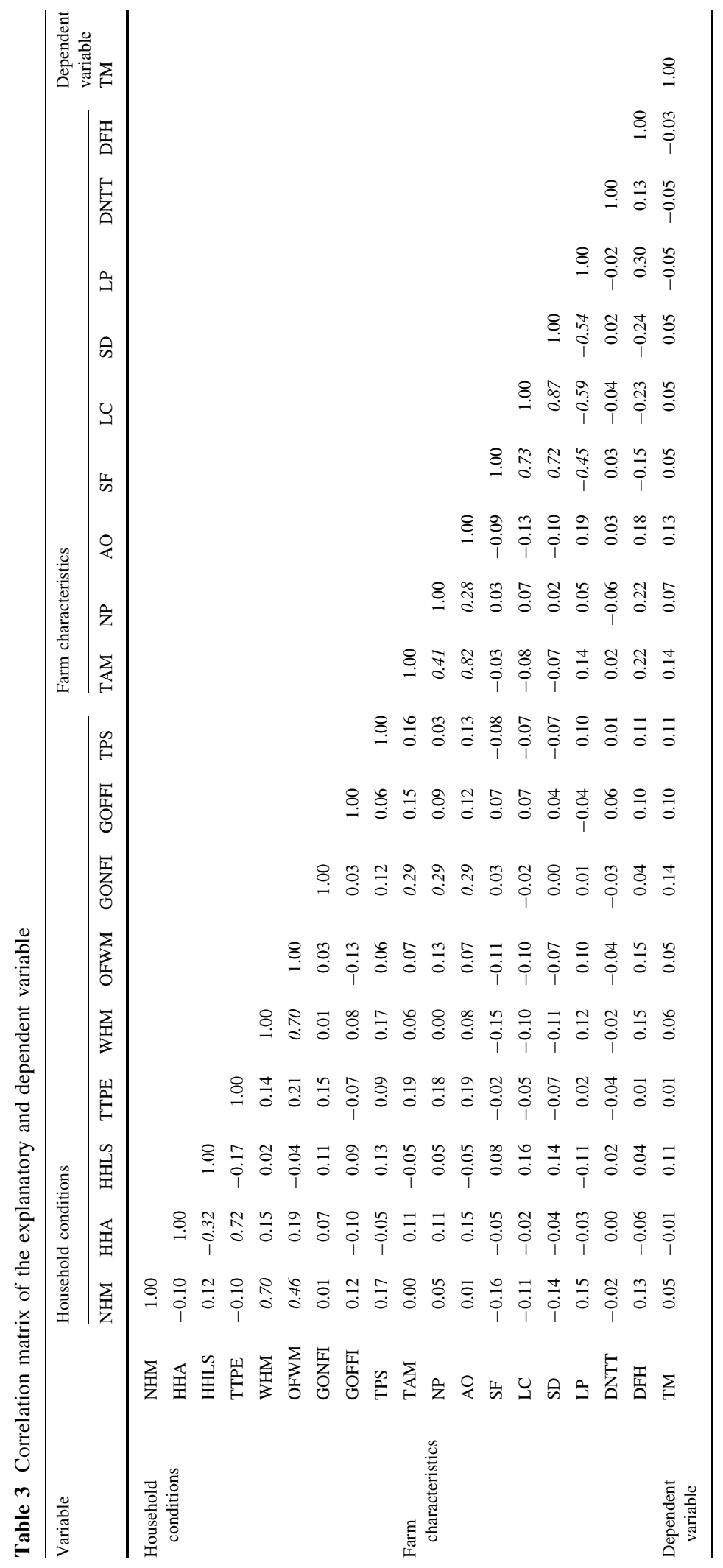


Table 4 Summaries of household condition, farm characteristic and composite models

\begin{tabular}{lccc}
\hline Test type & $\chi^{2}$ value & df & $p$ value \\
\hline $\begin{array}{l}\text { Household condition model } \\
\text { Omnibus tests of } \\
\text { model coefficients }\end{array}$ & 8.459 & 2 & 0.015 \\
$\begin{array}{l}\text { Hosmer-Lemeshow } \\
\text { goodness of fit test }\end{array}$ & 12.520 & 8 & 0.129 \\
$\begin{array}{l}\text { Farm characteristic model } \\
\text { Omnibus tests of } \\
\text { model coefficients }\end{array}$ & 4.537 & 1 & 0.033 \\
$\begin{array}{l}\text { Hosmer-Lemeshow } \\
\text { goodness of fit test }\end{array}$ & 4.805 & 8 & 0.778 \\
$\begin{array}{l}\text { Composite model } \\
\text { Omnibus tests of } \\
\text { model coefficients }\end{array}$ & 8.459 & 2 & 0.015 \\
$\begin{array}{l}\text { Hosmer-Lemeshow } \\
\text { goodness of fit test }\end{array}$ & 12.520 & 8 & 0.129 \\
\hline
\end{tabular}

characteristic factors showed some moderate correlations. The gross income of the on-farm variable explained the moderately positive correlation with some variables, such as total area managed (0.29), number of parcels (0.29) and area owned (0.29). Furthermore, the associations between the individual household condition factors, farm characteristics and timber management variable did not show a strong correlation.

\section{Logistic regression models}

The goodness of fit for the household condition model is indicated by the Chi square values and $p$ values of both the Omnibus and the Hosmer-Lemeshow tests. The Chi square values and the $p$ values for these tests for the respective logistic regression models indicate the model was able to distinguish between those farmers who managed and those who did not manage their timber trees (Table 4).

Household condition model

Based on the Wald test of Forward Likelihood ratio method, each of the household condition variables that entered the model were selected based on the significance level of $p$ value $(<0.10)$ in predicting the occurrence of timber tree management. The model shows that only gross incomes, both on-farm and off-
Table 5 Regression model and significant variables in the household condition, farm characteristic and composite models

\begin{tabular}{lccccc}
\hline Variable & B-value & $\begin{array}{l}\text { Standard } \\
\text { error }\end{array}$ & df & $p$ value & Exp(B) \\
\hline $\begin{array}{l}\text { Household condition model } \\
\quad \begin{array}{l}\text { Gross on-farm } \\
\text { income (GONFI) }\end{array}\end{array}$ & 0.568 & 0.249 & 1 & 0.023 & 1.766 \\
$\begin{array}{l}\text { Gross off-farm } \\
\text { income (GOFFI) }\end{array}$ & 0.077 & 0.044 & 1 & 0.082 & 1.080 \\
$\begin{array}{l}\text { Constant } \\
\text { Farm characteristic model }\end{array}$ & -3.726 & 1.610 & 1 & 0.021 & 0.024 \\
$\begin{array}{l}\text { Total area managed } \\
\text { (TAM) }\end{array}$ & 0.664 & 0.315 & 1 & 0.035 & 1.943 \\
$\begin{array}{l}\text { Constant } \\
\text { Composite model }\end{array}$ & 0.432 & 0.145 & 1 & 0.003 & 1.540 \\
$\begin{array}{l}\text { Gross on-farm } \\
\text { income (GONFI) }\end{array}$ & 0.568 & 0.249 & 1 & 0.023 & 1.766 \\
$\begin{array}{l}\text { Gross off-farm } \\
\text { income (GOFFI) }\end{array}$ & 0.077 & 0.044 & 1 & 0.082 & 1.080 \\
Constant & -3.726 & 1.610 & 1 & 0.021 & 0.024 \\
\hline
\end{tabular}

farm $(p$ value $=0.023$ and 0.082$)$, significantly influenced timber tree management when all household condition variables were considered (Table 5). The positive OR $(\operatorname{Exp}(B)=1.76$ and 1.08) on the gross incomes of both on-farm and off-farm variables indicates that with a positive one unit change in the value of timber tree management there will be an increase of 1.76 in gross on-farm income and 1.08 in gross off-farm income.

Farm characteristic model

The farm characteristic model confirms total area managed as a significant variable, with $p$ value $<0.10$, which explained household heads management of their timber trees, when all the farm characteristic variables were judged together (Table 5). The positive OR $(\operatorname{Exp}(B))$ of 1.94 for the total area managed variable indicates that the OR of timber management increased by a factor of 1.94 for the total area managed variable.

\section{Composite model}

The composite model comprises all household condition and farm characteristic variables. It allows selected variables, based on the significance level $(<0.10)$ to enter the model predicting the determining factors of timber tree management. This implies that 
both household condition and farm characteristic variables could be important in encouraging smallholder farmers to manage their timber trees. However, the Wald test of Forward Likelihood ratio method only selected the gross on-farm and off-farm income variables, based on the significance of improvement ( $p$ value $=0.023$ and 0.082 ), as factors affecting the likelihood of managing timber trees (Table 5). The positive OR $(\operatorname{Exp}(B)=1.76$ and 1.08) of gross income, for both on-farm and off-farm variables, indicates a similar relationship for the household condition model.

\section{Discussion}

The decision-making process of smallholder farmers is part of their overall livelihood strategy to balance livelihood objectives, household possibilities and constraints (van Noordwijk et al. 2001). Kragten et al. (2001) and Byron (2001) agreed that the decision-making process by smallholders allocates household assets to achieve a high level of expected net benefits, while the critical risk factors are concurrently minimized. In this study, household heads allocated household members (labor) to implement a range of tasks in timber production systems: planting good quality local seedlings, pruning tree branches for fuelwood and harvesting activities. The more family labor available, the greater the family labor that tended to be allocated to timber management activities. Sood (2006) stated that family labor is generally allocated to farm cultivation, with an increase in the amount of family labor available significantly affecting the diversity of agroforestry adoption. However, Scherr (1995) argued that farmers for whom labor is the major constraint typically use that labor efficiently; if labor becomes unavailable for timber management, farmers may respond by increasing the cultivation of associated crops.

Farmers' experience in managing timber trees is associated with their age. Timber farming is more common with older, experienced farmers. However, some older farmers with considerable experience were hampered by poor literacy skills from managing to realize the value of their trees. Sunkar (2008) reported that, in general, farmers in Gunungkidul were undertaking farming activities through inherited traditions, which have evolved over decades of experience, observation, and trial-and-error problem solving. Thus, the possibility of adopting a new farming and tree management system was slim unless farmers had seen and experienced the results. Similarly, Franzel and Scherr (2002) found that better education levels help farmers in Africa adopt more agroforestry innovations.

Access to land is an important factor in determining farming strategies. The total area of agricultural land owned or managed had positive implications on the proportion of agricultural land devoted to the timber trees, annual farm production and on-farm income. Secure land and tree tenure have been identified as prerequisites for the development of smallholder tree farming systems (Roshetko et al. 2008). Shively (1999) identified two conditions strongly associated with the proportion of agricultural land devoted to the tree crops: (i) larger farm size is positively correlated with number of trees planted and (ii) as farm size increases, the share of land devoted to trees decreases. Fixed costs include the time and investment required to obtain planting materials, as well as the expertise for developing and managing timber production systems. However, farmers with small farms $(<0.5$ ha $)$ in Gunungkidul region allocated around $10 \%$ of their land for growing timber trees (Rohadi et al. 2011).

Soil fertility, farm surface and soil depth variables in the Gunungkidul region are affected by the topography. Land on the lower slopes tends to have good soil fertility with thick soil layers, and farm surfaces with less karsts that are relatively flat. In the last 50 years, soil productivity increased in the sloping areas of this region, as smallholder households established various timber production systems and developed terraces on the slopes. Young (1997) and Jose (2009) stated that tree cultivation can help maintain or improve agricultural productivity by improving soils through enhancement of soil organic matter, nutrient retrieval and recycling, nitrogen fixation, water infiltration and storage capacity. According to Sabastian (2012), teak and acacia tended to grow faster on steeper slopes, while mahogany demonstrated the best growth on slight slopes in the Gunungkidul region. Therefore, these timber species in the agricultural landscape has improved soil fertility and soil depth in the last five decades.

When considering all factors equally, both the household condition and the composite model found that off- and on-farm incomes for timber management 
families were higher by 1.1-1.8 times, respectively, compared to families that did not grow timber. The availability of more on- and off-farm income increases the likelihood that farmers will adopt timber production technologies, such as quality planting material and better silvicultural management. According to Byron (2001), farmers who have more income and spare family labor can afford to wait for the revenue from growing trees for timber production. Also, the possibility of adopting timber management increased as farmers managed larger areas of land. As the area of agricultural land managed increases, farmers have opportunities to enhance timber tree production by considering the proportion of agricultural land devoted to timber trees and by applying silvicultural management. Of course, farmers also have to consider the spatial distribution of timber trees and species composition in respect to the farming system and competition with crops.

Agroforestry systems typically serve to reduce farm risk by diversifying crop production, contributing to food security and producing timber trees that can be sold for cash in an emergency (Scherr 1995). The effects of risk on adoption and management of intercropping and silvicultural technologies can be extended to agroforestry. Higher on-farm income and access to larger areas of agricultural land provide opportunities for smallholder farmers to minimize some farm risks and to adopt agroforestry technologies, including silvicultural techniques. Similarly, Pattanayak et al. (2003) found that agroforestry adoption is influenced by factors related to market incentives, biophysical farm conditions, resource endowments (family labor, land, and on- and off-farm income), risk and uncertainty, and household preferences.

Smallholder farmers tend to maintain the practices with which they are familiar and comfortable. However, they can and will adopt new practices under certain conditions. Byron (2001) argued that smallholders' decisions to change practices are often made when they are under pressure from competitive markets, declining yields, increasing input costs, or the need to accumulate emergency cash reserves. The research presented in this article shows that by reallocating household labor to silvicultural practices, farmers who can generate more on- and off-farm incomes tend to manage their timber trees intensively compared to farmers who do not apply silvicultural management. Competitive markets for high quality logs and improved income generation from timber production for farmers may encourage other farmers to adopt agroforestry options and more intensive management of their tree crops.

Timber production is viable for all farmers, with farmers who practice silvicultural management rewarded with higher incomes. While silvicultural management is correlated with farmers who have higher incomes and more land, this does not mean poor farmers cannot or will not practice silviculture. However, poor farmers' limited resources (including labor) and risk aversion results in limited practice of silviculture. Roshetko et al. (2013) reported that the adoption of simple silvicultural practices by poor farmers has proven to be viable. With market demand for timber increasing and supplies from forests decreasing, opportunities for smallholder timber production are enhanced (Roshetko et al. 2008). This makes the adoption of silvicultural management by poor farmers likely and profitable.

Logistic regression analysis of key attributes and the magnitude of the attributes affecting the adoption of timber management practices could help in designing agroforestry extension approaches. The present study implies that extension agencies and policy makers should focus on building the capacity of farmers to adopt silvicultural management in situations similar to that of the case study region. Further studies could investigate how different tree and crop species' mixes and timber tree management (spacing, pruning and thinning intensity) are affected by household and farm attributes, and how the returns from management options might be optimized.

\section{Conclusions}

In terms of understanding the influences of key household and farm attributes on the management of timber trees by smallholders in Gunungkidul, there are a number of conclusions drawn from this study. Based on the livelihood strategies theory, farmers in Gunungkidul are identified as "resource optimizers" in achieving household livelihood objectives. Through their decision-making processes, farmers allocate family labor to various cultivation activities. Farmers with more land tend to have higher on-farm income and devote greater areas to tree crop production. The management intensity of timber production systems is 
positively associated with higher on- and off-farm incomes and a larger total agricultural area. The results of this study suggest that agroforestry extension programs in the case study or similar regions could improve non-adopters' livelihoods by focusing on the use of quality planting material and proactive silvicultural management as these will deliver higher returns per unit of labour, so long as inputs are affordable.

Acknowledgments The research reported in this paper was facilitated through the Australian Centre for International Agricultural Research-supported project, 'Improving economic outcomes for smallholders growing teak in agroforestry systems in Indonesia' (FST/2005/177), lead by the Center for International Forestry Research and the World Agroforestry Centre. We thank other members of the research team and for their assistance with this work. We also thank the farmers who participated in the research and Robert F. Finlayson for editing the paper.

\section{References}

Baumgart-Getz A, Prokopy LS, Floress K (2012) Why farmers adopt best management practice in the United States: a meta-analysis of the adoption literature. J Environ Man 96(1):17-25

Bertomeu M (2004) Smallholder timber production on sloping lands in the Philippines: a system approach. World Agroforestry Centre Southeast Asia Regional Program, Los Baños

Byron RN (2001) Keys to smallholder forestry in developing countries in the tropics. In: Harrison SR, Herbohn JL (eds) Sustainable farm forestry in the tropics: social and economic analysis and policy. Rainforest CRC, Edward Elgar, pp 211-226

Ellis F (2000) Rural livelihoods and diversity in developing countries. Oxford University Press, Oxford

Filius AM (1997) Factors changing farmers' willingness to grow trees in Gunungkidul (Java, Indonesia). Neth J Agric Sci 45:329-345

Fisher L, Bunch R (1996) Challenges in promoting forest patches in rural development efforts. In: Schelhas J, Greenberg R (eds) Forest patches in tropical landscapes. Island Pressure, USA, pp 381-400

Franzel S, Scherr SJ (eds) (2002) Trees on the farm: assessing the adoption potential of agroforestry practices in Africa. CABI Publishing in association with International Centre for Research in Agroforestry (World Agroforestry Centre), Nairobi

Jose S (2009) Agroforestry for ecosystem services and environmental benefits: an overview. Agrofor Syst 76:1-10. doi:10/1007/s10457-009-9229-7

Kragten M, Tomich TP, Vosti S, Gockowski J (2001) Evaluating land use systems from a socio-economic perspective. ASB Lecture Note 8, International Centre for Research in Agroforestry, Bogor, p 3-6
Manurung GES, Roshetko JM, Budidarsono S, Kurniawan I (2008) Dudukuhan tree farming systems in West Java: how to mobilize self-strengthening of community-based forest management? In: Snelder DJ, Lasco RD (eds) Smallholder tree growing for rural development and environmental services, lessons from Asia, Advances in Agroforestry 5. Springer, Bonn, pp 99-116

McGinty M, Swisher M, Alavalapati J (2008) Agroforestry adoption and maintenance: self-efficacy, attitudes and socio-economic factors. Agrofor Syst 73(2):99-108

Mercer D (2004) Adoption of agroforestry innovations in the tropics: a review. Agrofor Syst 58:311-328. doi:10.1023/ B:AGFO.0000029007-85754-70

Mercer DE, Miller RP (1998) Socio-economic research in agroforestry: progress, prospects, and priorities. Agrofor Syst 38:177-193. doi:10.1023/A:1005964830133

Nair PKR, Dagar JC (1991) An approach to developing methodologies for evaluating agroforestry systems in India. Agrofor Syst 16:55-81. doi:10.1007/BF00053197

Nibbering JW (1999) Tree planting on deforested farmlands, Sewu Hills, Java, Indonesia,: impact of economic and institutional changes. Agrofor Syst 57:173-186

Pallant J (2007) SPSS survival manual: a step by step guide to data analysis using SPSS for Windows version 15 , 3rd edn. Open University Press, Milton Keynes

Pannell DJ, Marshall GR, Barr N, Curtis A, Vanclay F, Wilkinson R (2006) Understanding and promoting adoption of conservation practices by rural landholders. Aust J Exp Agric 46(11):1407-1424

Pattanayak SK, Mercer DE, Sills E, Yang JC (2003) Taking stock of agroforestry adoption studies. Agrofor Syst 57:173-186

Rohadi D, Roshetko JM, Perdana A, Blyth M, Nuryartono N, Kusumowardani N, Pramono AA, Widyani N, Fauzi A, Sasono J, Sumardamto P, Manalu P (2011) Improving economic outcomes for smallholders growing teak in agroforestry systems in Indonesia. Final report of project FST.2005/177, Australian Centre for International Agricultural Research, Canberra

Roshetko JM, Lasco RD, Delos Angeles MD (2007) Smallholder agroforestry systems for carbon storage. Mitig Adapt Strat Glob Change 12:219-242

Roshetko JM, Snelder DJ, Lasco RD, van Noordwijk M (2008) Future challenge: a paradigm shift in the forestry sector. In: Snelder DJ, Lasco RD (eds) Smallholder tree growing for rural development and environmental services, lessons from Asia, Advances in Agroforestry 5. Springer, Bonn, pp 453-485

Roshetko JM, Rohadi D, Perdana A, Sabastian G, Nuryartono N, Pramono AA, Widyani N, Manalu P, Fauzi MA, Sumardamto P, Kusumowardhani N (2013) Teak agroforestry systems for livelihood enhancement, industrial timber production, and environmental rehabilitation. For Trees Livelihoods 22(4):241-256

Sabastian GE (2012) Enhancing the sustainability of smallholder timber production systems in the Gunungkidul region, Indonesia. PhD thesis, Australian National University, Canberra

Sabastian GE, Roshetko JM, Anggakusuma D, Pramono AA, Heriansyah I, Fauzi A (2009) Smallholder teak-based farming management in Gunungkidul, Yogyakarta: current 
practice, obstacles and improvement options. ACIAR Project Report, Australian Centre for International Agricultural Research, Canberra, and World Agroforestry Centre Southeast Asia Regional Program, Bogor, Indonesia

Santos FM, Bertomeu M, Van Noordwijk M, Navarro R (2012) Understanding forest transition in the Philippines: main farm-level factors influencing smallholder's capacity and intention to plant native timber trees. Small-scale For 11:47-60

Saxena NC, Ballabh V (1995) Farm forestry and the context of farming systems in South Asia. In: Saxena NC, Ballabh V (eds) Farm forestry in South Asia. Sage Publications, New Delhi, pp 23-50

Scherr SJ (1995) Economic factors in farmer adoption of agroforestry: patterns observed in Western Kenya. World Dev 23(5):787-804

Shively GE (1999) Risks and returns from soil conservation: evidence from low-income farms in the Philippines. Agric Econ 21:53-67

Soerianegara I, Mansuri (1994) Factors which determine the success of regreening in Gunungkidul, Central Java. J Trop For Sci 7(1):64-75

Sood KK (2006) The influence of household economics and farming aspects on adoption of traditional agroforestry in Western Himalaya. Mt Res Dev Int Mt Soc 26(2):124-130
Statistics of Gunungkidul Regency (2009) Gunungkidul in figures 2009. Katalog BPS:1102001.3403, collaboration between the Regional Development Planning Board of Gunungkidul and Statistics of Gunungkidul Regency, Yogyakarta, Indonesia

Sudiharjo AM, Notohadiprawiro T (2006) Sekuen produktivitas lahan di wilayah karst Karangasem, Kecamatan Ponjong. Ilmu Tanah Universitas Gadjah Mada, Yogyakarta, Indonesia, Kabupaten Gunungkidul

Sunkar A (2008) Sustainability in karst resources management: the case of the Gunung Sewu in Java. PhD thesis. University of Auckland, New Zealand

Tabachnick BG, Fidell LS (2007) Using multivariate statistics, 5th edn. Pearson Education, Boston

Van Der Poel P, Van Dijk H (1987) Household economy and tree growing in upland Central Java. Agrofor Syst 5:169-184

Van Noordwijk M, Tomich TP, Verbist B (2001) Negotiation support models for integrated natural resource management in tropical forest margins. Conserv Ecol 5(2):21

Waltham AC, Smart PL, Friederich H, Eavis AJ, Atkinson TC (1983) The caves of Gunung Sewu, Java. Cave Sci 10(2):55-96

Young A (1997) Agroforestry for soil management, 2nd edn. CABI publishing, Wallingford 